\title{
Using Sensory Detail Chart in Collaborative Experiential Learning to Increase Quality of Students' Descriptive Writing
}

\section{Tiarma Marpaung and Erny S. N. Hambandima}

Artha Wacana Christian University, Kupang

\section{Abstract}

Having writing as the most challenging skill in EFL learning, students need to experience a stimulating learning activity to develop their skill in writing practices. Therefore, EFL teachers need to put an English language exploration of writing. This study promoted the use of a sensory detail chart in a collaborative experiential learning (CEL) exercise aimed at increasing the quality of EFL students' descriptive writing. The researcher implemented this learning method by doing classroom action research (CAR) in two cycles in which 26 students participated. The use of sensory detail chart (SDC) stimulated students to explore their five senses to specify any properties

Corresponding Author:

Tiarma Marpaung

tiar.lulan@gmail.com

Received: 23 January 2019

Accepted: 26 February 2019

Published: 17 March 2019

Publishing services provided by Knowledge E

(c) Tiarma Marpaung and Erny S. N. Hambandima. This article is distributed under the terms of the Creative Commons

Attribution License, which permits unrestricted use and redistribution provided that the original author and source are credited.

Selection and Peer-review under the responsibility of the International Seminar on Language, Education, and Culture Conference Committee.

\section{G OPEN ACCESS} or characteristics of the object described. Meanwhile, the implementation of CEL accommodated the students to develop their communicative competence as well as to help them to gain more ideas in describing the object. The researcher used preand post-tests as research instruments to measure the quality of students' descriptive writing. The tests asked the students to write descriptive texts on topics given. From the tests, the researcher found that the quality of students' descriptive writing increased by $36.58 \%$ in the first cycle and $56.53 \%$ in the second cycle. From these results, the researcher concluded that the use of sensory detail chart in collaborative learning was successful in increasing the quality of students' descriptive writing. Thus, she argues that the use of sensory detail chart in a collaborative learning environment is effective in stimulating students' writing in a foreign language, especially in writing descriptive text.

Keywords: collaborative experiential learning, sensory detail chart, descriptive text

\section{Introduction}

Both teacher and students are responsible for EFL learning to be successfully founded to achieve the goals of language learning. Fluency in using the language orally and written becomes one of the goals set in its lesson plan. However, EFL learners still face challenges in their learning. The environment in which they live daily does not provide sufficient opportunity for them to practice and use the target language frequently. This 
has been one of many common problems faced by EFL learners (Akbari, 2015). In this case, students feel that they do not necessarily speak English outside the classroom as their society does not use English as daily communication. Therefore, EFL teachers need to provide learning that can reinforce the students to use the target language more often in the classroom.

Being more communicative is one of the many benefits gained from putting students in collaborative work. In line with cooperative learning, collaborative learning psychologically helps students to reduce anxiety and reinforce them to be more active and engaged (Laal \& Ghodsi, 2012). Collaboration can also help students to develop their critical thinking when trying to find the best solution to one subject matter. Students can be more interactive during the process of thinking as they do it with their collaborators.

Students with diversities can also stimulate one another's creative thinking to be shared during collaborative work. When students share their ideas in groups, each individual is enriched with more information. To do it well, students need to develop their arguments by supplying their statements with specific reasons or details. This is to help students who experience difficulty in writing. A Collaborative work can help students increase their writing quality, especially in increasing the fluency of writing. Marpaung (2017) mentions that her students can increase the number of content words used in writing English descriptive text by $62.44 \%$ after her first cycle of classroom action research and by $138.17 \%$ after the second cycle of the research. It shows that by working in groups, students with their divergent thinking can be more creative in expressing their thoughts and gain more detail information in their writing.

Students can also supply their ideas with details by direct observation or experience. Thus, teachers need to accommodate their students with an experiential learning which leads them to direct observation and action on the subject matter. Creativity and critical thinking take place as students observe and experience things on site. They are encouraged to be able to express what they observe into words and critically sort words which best describe it.

Experiential learning is conducted in a cycle shown in Figure 1. It starts by having students in a concrete experience. Then it continues by making them observe and reflect on what they have experienced. After that, they can conceptualize how to make better results of learning. Finally, students begin their active experience to make their abstract concept real. These steps continues in another cycle needed to improve learning and the students.

Experiential learning aims at giving students a holistic education as a whole person (Kolb \& Kolb, 2017). It can engage students in the learning physical, emotionally, and 


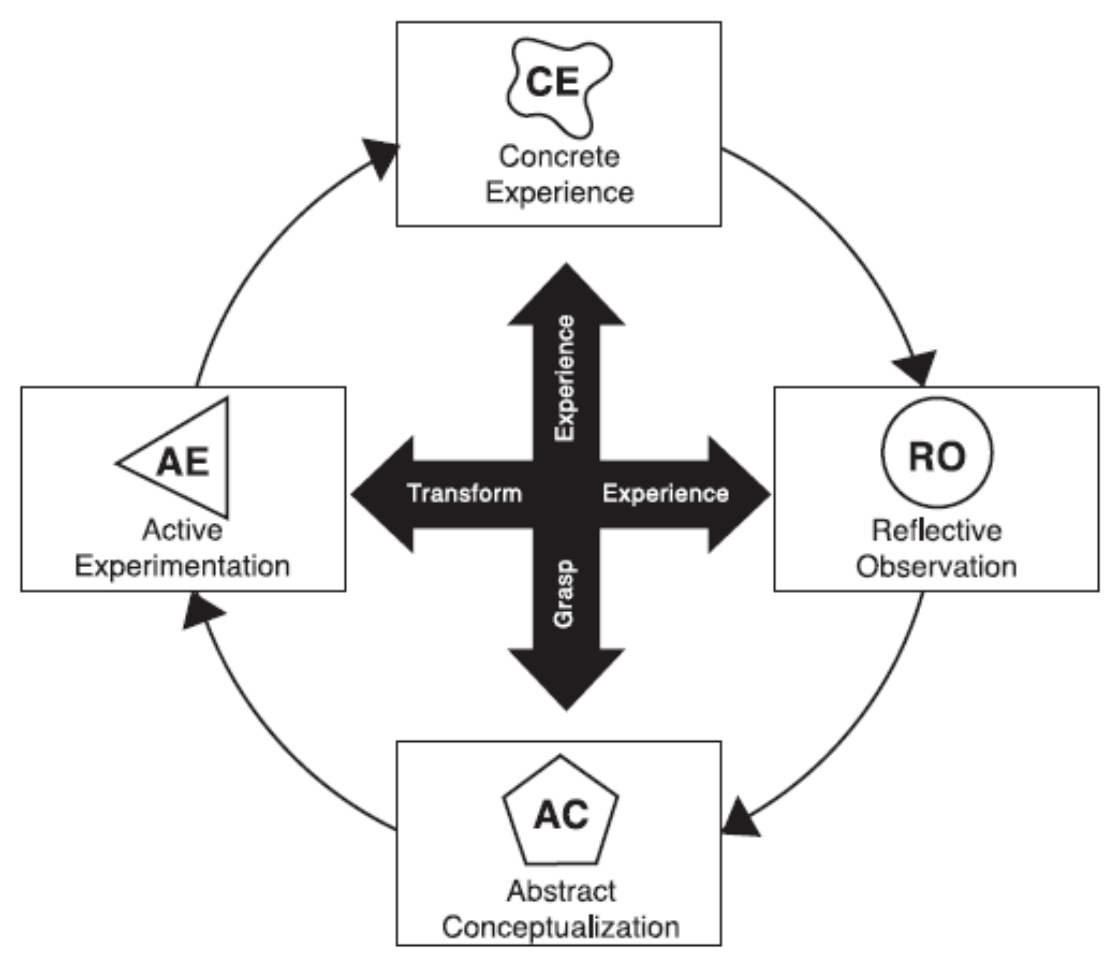

Figure 1: The Cycle of Experiential Learning (Kolb \& Kolb, 2017).

intelligently. It also encourages students to not only read, listen, talk, and write about one subject matter. This learning reinforces the learners to experience directly about the subject matter. Therefore, experiential learning can help students develop their whole person, especially in critical thinking. It is because experiential learning builds a more comfortable learning environment. Learning in this way can lead students to explore their maximum potentials, especially in expressing ideas, giving arguments, and detail information on the subject discussed. It is because they have more freedom in conducting their learning. Teachers monitoring is only to make sure that their learning runs well. Students have the freedom to provide solutions to any problems emerging in the process of learning.

To help students in managing their ideas and details, teachers then need to facilitate their students with an organizer. In this study, sensory detail chart is used to help students manage their ideas. Sensory detail is used as a strategy in the learning conducted. This strategy allows students to explore their five senses (senses of sight, taste, hearing, smell, and touch) to describe the object they observe during experiential learning. Though it is commonly used for young learners, sensory detail strategy is still rarely used for learners of higher education. Thus, the researcher is highly motivated in applying this strategy in the experiential learning she conducted in her study. 
This study focuses on stimulating students' writing skill of descriptive text as well as on improving its quality. Descriptive text is fundamental to most types of texts, such as narrative, recount, and expository texts (Knapp and Watkins, 2005). To produce a qualified descriptive text, students need to have sufficient knowledge of its generic structure and language features. Adequate knowledge on the text structure and grammar of any text type is prominent for the students since the lack of it has become the common problem (Alfaki, 2015).

As an approach to students' learning, the researcher implemented a collaborative experiential method in which students learn to describe by having a direct observation to the object and experience learning in groups to gain more ideas during discussion. In this kind of learning students are expected to be more active and responsible in thinking and doing discussion (Totten, et al., 1989 in Dooly, 2008). Developed by Kolb (1984), experiential learning itself is aimed at giving students a chance to experience learning close to the object of observation to get more detail and accurate descriptions (Sharlanova, 2004). In implementing collaborative experiential learning, the researcher facilitated her students with sensory detail chart (SDC) to help the student in organizing ideas during observation.

The use of SDC leads students to their best exploration of their five senses. This is also expected to reinforce students to think critically and creatively in expressing their descriptions on the object. Students need this ability to be able to write well (Rief, 2006 in Westwood, 2008). Gee (2012) also mentioned that good writing empowers all senses. During learning, students explored their ability to see, hear, taste, smell and feel/touch and express the senses inappropriate words and phrases.

Reflected from her EFL writing classes, the researcher found that most of her students' writing does not meet the qualifications of good writing. Thus, the researcher needs to give a stimulating learning to help students gain more critical and creative thinking in writing practices.

\section{Method}

This research is intended to intervene students' learning for they can improve their writing quality through a classroom action research by implementing a collaborative experiential learning (CEL) facilitated with a sensory detail chart (SDC), specifically to improve the students' descriptive writing. Conducted in two cycles, the classroom action research was held in four steps. These steps were planning, acting, observing, and reflecting. Steps of the experiential learning cycle (concrete experience, reflective observation, 
abstract conceptualization, and active experiment) were integrated in each cycle of the classroom action research. Before the implementation, the researcher gave pre-test to the 30 students participated. Post-tests were done after each cycle of the research. The researcher used pre- and post-tests as the technique of data collection. The tests are given to measure students' descriptive writing assessed by two inter-raters using NWREL - Northwest Regional Educational Laboratory's 6 traits of writing rubric which includes ideas, organization, voice, news choice, sentence fluency, and convention. These traits range in 4 levels: beginning, emerging, developing, and maturing. The researcher has used a descriptive quantitative method to analyze the data gained from the tests.

\section{Findings and Discussion}

\subsection{Pre-test}

Before the intervention, the researcher gave a pre-test for the students to write a descriptive text on a lined-F4 sized of paper. The students chose one of two familiar topics. It was either Oesapa Beach or Lasiana Beach. Students could provide their own dictionary as a reference for vocabulary. The students should write the text in 45 minutes. Most students submitted their paper before 45 minutes. However, the researcher found that there were only three out of 26 students who wrote more than half a page. Besides the grammatical and mechanical problems, it obviously shows that the lack of vocabulary becomes the major problem of the students in writing.

Figure 2 shows one of the students' descriptive writing in the pre-test. Students frequently make mistakes in the mechanic of writing and in grammar. Capitalizations, punctuations, and subject-verb agreement seem to be the most challenging in this writing. These challenges thus affect the convention trait as one of the traits of writing quality. The lack of vocabulary also crucially affects the sentence fluency as another trait of writing quality. However, most students seem to have ideas to begin writing. They also have their own way to express their ideas in their writing. The following table shows the results of students' descriptive writing quality in the pre-test.

TABLE 1: Mean Scores of Writing Quality in Pre-test.

\begin{tabular}{|c|c|c|c|c|c|}
\hline Ideas & Organization & Voice & Word choice & Sentence fluency & Conventions \\
\hline 57.21 & 47.11 & 52.40 & 48.55 & 40.84 & 36.53 \\
\hline
\end{tabular}

Table 1 shows the scores of all traits of writing quality in the pre-test. Three traits are still below the total average score. Students gain the lowest score in convention 


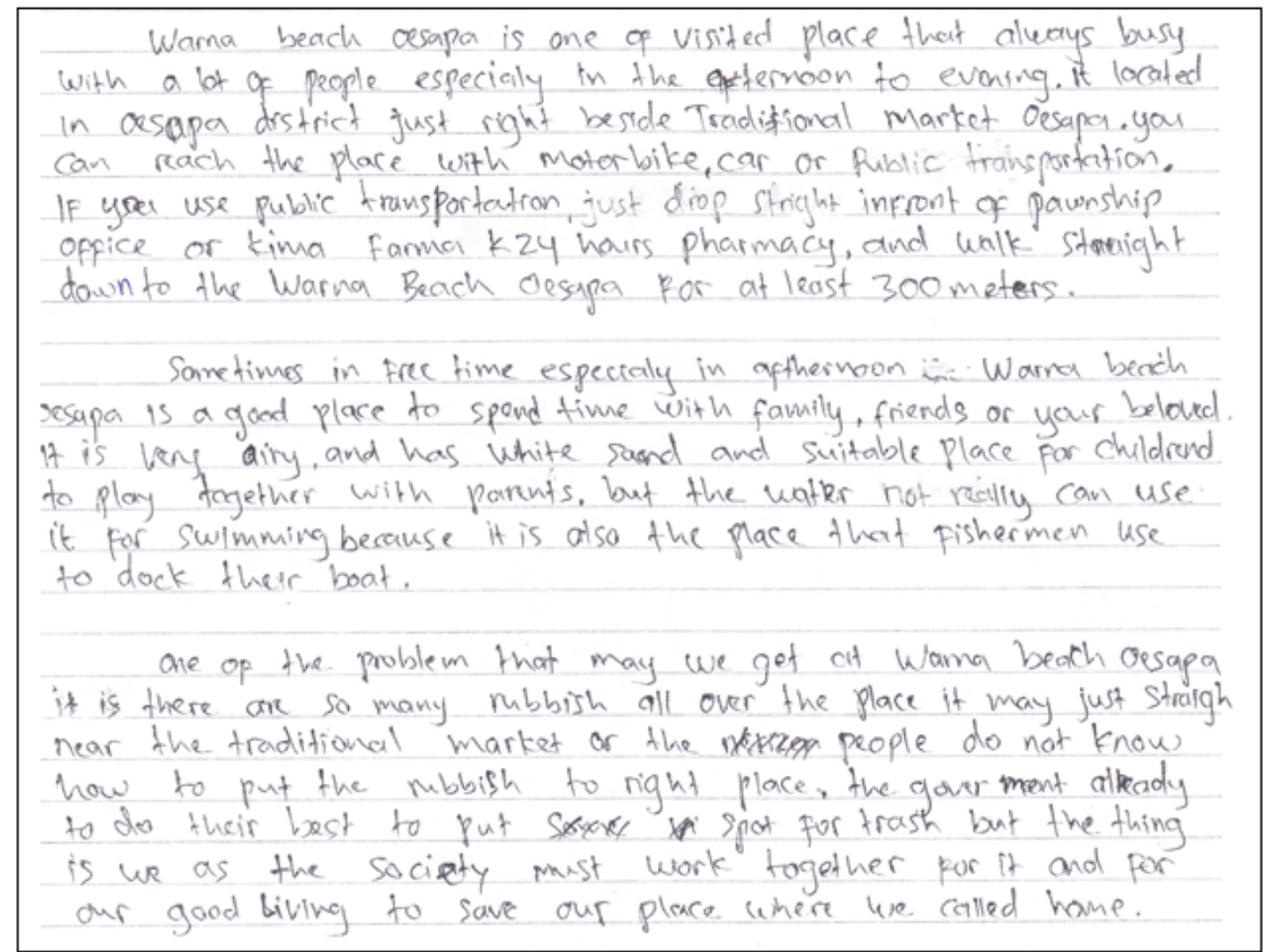

Figure 2: The Longest Descriptive Writing in Pre-Test.

trait. It means that students still have writing errors in grammar and some mechanics of writing, such as capitalization, punctuations, and paragraphing. The trait of sentence fluency is the penultimate lowest score. It shows that students need to work more on their vocabulary and in putting words into sentences correctly.

In her study, the researcher also found that there were 14 out of 26 students participated in pre-test whose writing quality scores are still below 47.12. It means that there are $53.84 \%$ students whose descriptive writing quality is below the average score. Based on the institutional academic grading scale, there is only 1 student in excellent level, and most of them (13 students) are in the very poor level $(\leq 40.99)$. In the very poor level, students should not pass the test.

The average score of each trait of students' writing quality in pre-test is mostly at the level of beginning and emerging. The highest score the students have in is the trait of ideas and the lowest score is in the trait of conventions. It means that most students might have a glimpse of ideas emerged in writing their descriptive text but still are still struggling in producing accurate convention in the paragraphs. 


\subsection{Cycle 1}

\subsubsection{Planning}

The first cycle of classroom action research was conducted by planning, acting, observing, and reflecting. Common preparations before starting the research were done by meeting the students to inform them about all things they would do in the learning process and providing all administrative class documents such as the learning materials, and research instruments such as attendance list, sensory detail chart, a vocabulary of senses, and observation checklist. Supporting learning equipment and media such as PPT and visual aids were also prepared in this session.

The first step of experiential learning begins at this stage of the research. It was done in the pre-test. The researcher asked the students to write a descriptive text on the given topic. They were asked to write the descriptive text within 45 minutes. They were allowed to refer to any dictionary to help them write. After the students finished writing, the researcher asked the students about their writing. They admitted that they were not quite satisfied with their writing during pre-test. They mentioned that it lacked grammar accuracy and vocabulary. It was hard for most students to express their ideas in proper words and appropriate sentences. Therefore, many of them used Google translator during the pre-test to help them write in English. Unfortunately, the translation tool was not sufficiently helpful to produce a good quality of writing.

Thus, the researcher helped them to figure out how to produce better descriptive writing by introducing the sensory detail strategy. They practiced how to explore their five senses to describe things they could see in the pictures shown. The researcher also gave them some words of sensory words and asked them to classify based on the senses. To help the students organize the words, the researcher asked them to make a sensory detail chart. Then they tried to put those words into sentences.

Further, the students also learned about the text organization of the descriptive text. They also identified its language features in texts shown on the PPT slides. This session helped the students to gain their abstract concept on descriptive text. It also supported the students to better comprehension of the descriptive structure before they were involved in the experiential learning. 


\subsubsection{Acting}

After presenting all the materials in the previous stage, the researcher delivered students in the process of 90 minutes-collaborative experiential learning held in the first location (Oesapa beach). The students continued the experiential learning cycle by doing an active experiment. In this step of learning, each student was facilitated with a sensory detail chart to help them organize their ideas during their exploration of five senses. They did the exploration together in groups of 4 to 5 . This group-work should add more details of description to each student.

During the exploration, students should fill in SDC by consulting the sensory words or phrases to the vocabulary of senses provided before the learning. Students in groups were dispersed along the beach. They also discussed their opinions to describe the object by using sensory words. They enjoyed their sense of touch when they felt the sand or the sea water. They also felt relaxed as they saw the beach and the ocean view. The smell of the air gave them different sensation during their exploration. Those senses exploration

\subsubsection{Observing}

The researcher observed that most students enjoyed the process of CEL. Collaborative learning did help the students to gain more confidence in communicating their ideas. They also enjoyed their senses exploration. They enjoyed their sense of touch when they felt the sand or the sea water. They also felt relaxed as they saw the beach and the ocean view. The smell of the air also gave them different sensation during their learning. The students were excited as they might not get the same experience if they study in their classroom. However, since there was a lack of control from the researcher, they mostly communicated in their local or second language. The lack of control happened because students in groups dispersed around the location of experiential learning.

Apart from their excitement, students faced one common problem of having a collaborative learning. The problem happened because passive students stayed passive during the discussion. Less motivation or less confidence of the passive students and the domination of the active ones during the discussions became the major reasons for this emerging problem. Students who were passive in expressing their ideas during the discussion felt that their ideas were not representative enough to be accepted by the group. Those who tried to express their ideas but were not heard decided to be silent and be listeners. Those who stayed passive then depended on the dominant ones 
during the discussion and in working on SDC. However, the researcher found that there were passive students reinforced to express their ideas as they felt relaxed during the learning process. It shows that CEL can encourage and reinforce the students to give their best for their group and for better results of discussion. When everyone in the group shares ideas, all students can gain more sensory words to be used in their descriptive writing. It is because each student may have a different perspective or different target of observation. It means that they can have more detail descriptions on what they see, hear, smell, touch, and taste.

\subsubsection{Reflecting}

There are some points to reflect from the first cycle. The first point is that the researcher needs to make sure that students have understood the importance of collaborative experiential learning so that they would be more engaged in all activities, especially exploration and discussions. Students should take the responsibility in learning to improve and develop their competence in English language skills, especially writing. The second point is that the researcher should give more time for the students to practice using SDC in organizing detail descriptions of the object. Then, the researcher needs to consider the conditions of the location and the time of learning. During the learning process, students complained about the heat of the sun. It caused certain students to feel unwell physically. The dazzling sunlight also made them difficult to do careful observation and fill in their SDC.

\subsection{Post-test 1}

After running the first learning intervention in Cycle 1, the researcher gave students the first post-test. The topic was about Oesapa Beach. In this test, students were facilitated with SDC and vocabulary of senses they used in the first cycle of learning as references. Students were not allowed to provide their own references during the test. They only could refer to the sensory words listed in the vocabulary of senses.

The test ran for 45 minutes. Students focused on writing their descriptive text. They looked more enthusiastic during the test. Everyone seemed to be more engaged in their own writing. Students wrote more fluently in this test. They produced more words and sentences on their test paper and used the given time well. Some of them even were still writing when the time ended. 
Figure 4 shows one of the students' descriptive writing which is the longest text in post-test 1. This text is still showing errors in the convention trait, especially in the use of articles and prepositions. It is also grammatically incorrect as it is inconsistent in the tense. Some mistakes also occur in the sentence constructions. However, it obviously shows the improvement of writing quality, especially in the traits of word choice and sentence fluency.

Oesapa Warna beach is beated in the Oesapa Vilager Kelapa Lima distriet, Kupang City. East Nusa Tenggara, inded very exotic. Oesapa whom beach be used as one of tourist attroctions in the fupang City. East Nusa Tenggara. The location of oesapa Matna beach is about $10 \mathrm{~km}$ from the kupaing city center. Toularis to the beads, it is not difficuit becouse it can be taken by the variety of vehieles like motorcycle or car. Once, when we was in the beach. everyone visiting that feel at home becauselltserved with the beavtiful scenery afternoon (sunset). There is also a number of small lopo (Find of a sinall heme, but just have rooft), and also seme merehants lined along the beach while peddling their merchandise, such as Jagung Bapae, Pisang Pepeng, the various types of cold drinks and hot drinf and be eqquiped with the entertainment music. Almost every day, hundreds of people flacking to visit the Orapa Warna beach. There are people that just eat. drink. listan to music, exyoy the sunset time and play football.

But, unfortunetly, the atmospher of the beach is change. Beach location side by side with one of troditional market, and due that every day the beach look very crowded with the visitors buyers and also the sellers. Beach began to appsar dirty. due to the act of humean that waste the gartaige radom, it is make beach become to unattractive looging. There are many sollers ardund the beach began to peddling ther merthandise. The fishermen also pulled their boats unorganize. The sea water looks dirty, and it coloured is brownish as mix between coffe and milk. Beach atmexpher sounds very noisy, by sound of waves, sound of the fishermen beat, saund of music, and also the sound of sedlers, buyers, visitors, who heard roudy, and not only that, there is alway hearing sound of muse and also of vehicle. Along the beach began the with the bad smell, such as the smen of garbuge pile, smell of fish and also sinell of sea water. In addition, ive also can feel the seft and destroyed garbage due by weathering process and wet sands, also sticky feeling of sea water. While that we also tasto the sharp tasting salty of sea water.

Ohe of citizens of Kupang oby, often ssit the Cesapa wama beach elaimid that, in addition can virit, it can also shooping the pitehen reeds due to the location of the beach side by side with the traditional. market: But he

also hope that, the kupang gouernment can reorganize the beach for be better, especially related to garbage that still pled on the beach or along the heach. So. Oesupa warna beach is the one place that are can visit when we bave free time. But, based on the visitors oprion, I hope the Kupang governmet. can reaganize or try to make a plan to parh the all of citizens to clean up the beach.

Figure 3: The Longest Descriptive Writing in Post-Test 1. 
The progress of the students' descriptive writing quality can be seen in the increase in the scores in all traits of writing quality. Students perform better scores mostly in the trait of ideas. The researcher believes that the direct observation and the five senses exploration during the experiential learning have helped the students in finding more ideas to express in their descriptive writing. The sensory detail chart also has made them easier in organizing their ideas so that they gain a higher score in the trait of organization.

Since the students can see, hear, smell, touch, and taste more things directly in the experiential learning, they can find more words to describe those things in their descriptive writing. The increase in score in the trait of organization and sentence fluency is quite high. However, most students still need to work harder in the latter trait mentioned as its score is still below the average score (see Table 2).

TABLE 2: Increase in Mean Scores of Writing Quality in Post-test 1.

\begin{tabular}{l|c|c|c|c|c|c|}
\hline & Ideas & Organization & Voice & Word choice & $\begin{array}{c}\text { Sentence } \\
\text { fluency }\end{array}$ & Conventions \\
\hline Post-test 1 & 78 & 67.5 & 67 & 67.5 & 57.5 & 49.5 \\
\hline Increase & 20.79 & 20.39 & 14.60 & 18.95 & 16.66 & 12.97 \\
\hline$\%$ & 36.33 & 43.28 & 27.86 & 39.03 & 40.79 & 35.51 \\
\hline \multicolumn{5}{r}{} \\
\hline \multicolumn{7}{r}{ Mean total in Post-test 1= 64.36; Increase in Mean= 17.24 (36.58\%) }
\end{tabular}

Table 2 shows that the students gain better scores in all traits of writing quality. They improve their ability in gaining ideas, in organizing the text, in deciding their voice of writing, in choosing words, in producing sentences, and in managing the convention of their descriptive writing. However, there are two traits that still need improvement as the scores are still below the average score.

The results of post-test 1 point out that the increase in students' writing quality is quite significant. The increase is delivered in the aspects of writing respectively in ideas by $36.33 \%$, in the organization by $43.28 \%$, in the voice by $27.86 \%$, in word choice by $39.03 \%$, in sentence fluency by $40.79 \%$, and in conventions by $35.50 \%$. The level of students' writing quality in post-test 1 has reached emerging to developing level. Then, based on the academic qualifications, there are five students whose writing is outstanding level as the highest level, and the lowest level reached in post-test 1 is poor level gained by 9 students. The results have become beginning evidence that the use of SDC in CEL has improved students' writing quality of descriptive text in terms of ideas, organization, voice, word choice, sentence fluency, and conventions.

The results of writing in Post-test 1 also indicate that the average score of students' writing quality has increased by $36.58 \%$. There are no students in the very poor level. However, compared to the pre-test results, the number of students whose score is below 
average has no increase. It means that not all students perform their best in writing. Thus, better improvement in the students' writing quality is expectedly to emerge after the second cycle of the research.

\subsection{Cycle 2}

\subsubsection{Planning}

After doing their first post-test which is their concrete experience of writing a descriptive text, students started doing their reflective observation on their writing. They were quite proud of their achievement. They also realized that they made some errors in the conventions. Some students were still struggling with organizing their ideas into wellwritten paragraphs. Most of them also needed to work on the mechanics of writing. These reflections helped the students to make an abstract conceptualization of how to write properly and how to write descriptive writing appropriately.

Before starting the second cycle of her classroom action research, the researcher planned the lesson of CEL by considering the reflected points of Cycle 1. She reminded her students about the generic structure and language features of a descriptive text. She also pointed out the use of adjectives to describe nouns and the use of adverbs to describe verbs. Students also did some exercises by making some sentences using the sensory words to describe some pictures prompted. She prepared new copies of SDC to the students to record their sensory words resulted from their direct observation in Cycle 2. An observation list and questionnaire as the research instruments were also prepared to monitor students' activities during the learning process and to ask their responses about CEL at the end of the lesson. The lesson of Cycle 2 was planned for outdoor activities of learning. Other administrative documents for the lesson were organized in this session.

\subsubsection{Acting}

Before doing the active experiment of collaborative experiential learning, the researcher gave them some instructions and reminded them of what they should do in this second cycle of the research. The lesson of CEL in Cycle 2 was held in the second location, Lasiana Beach. There was an open-air pavilion where students gathered to do some evaluations. After doing evaluations of the learning process in Cycle 1 and the post-test 1 result, the researcher divided the students into new groups. She appointed 6 students 
with the highest scores in post-test 1 to be the group leaders. The group leaders should, in turn, choose their group members of 4-5 persons. To all students in the groups, the researcher distributed the new copies of SDC. They also had their vocabulary of senses they used in Cycle 1.

In this session, the researcher reviewed and reminded the students about the structure of the descriptive text and the generic structure of the text. She also evaluated the sensory words used by the students in their descriptive writing of post-test 1, especially on the use of adverbs and adjectives in verb and noun phrases. Then, students delivered CEL in the next session to do exploration around the beach. They explored their five senses together in groups. They used SDC to organize their ideas based on each sense they explored and consulted the sensory words and phrases to the vocabulary of the senses provided. They filled in their SDC individually while they were observing and discuss with their group the proper words used to describe the objects observed.

When the students in groups collaborated on their ideas, they gain more detail descriptions to be used in their descriptive writing. Further, after group exploration, students noted down more detail descriptions from the other groups in the class discussion held at the end of the session. In this time, the researcher corrected the misuse or improper words in the description so that the students would produce better descriptive text.

\subsubsection{Observing}

The researcher observed the students' activities during the learning. She found that the students did enjoy the learning. They experienced such learning that stimulated their motivation in learning. They felt refreshed and did their learning well. Students were more engaged in the learning and more active in sharing ideas. They seriously explored their five senses and discussed the proper use of sensory words to describe the objects. Most students were benefited from the collaborative work and the use of SDC.

Some members of the groups parted around to look for a different view. This activity helped the groups to gain much more details in their descriptions. They enjoyed the location as it was more quiet and cooler than the previous location as there were more trees along the beach. This condition made the students spent more time in doing the exploration before the researcher called them to gather in the pavilion.

When students gathered in the pavilion, they shared their details written in their SDC during the direct observation. There were new sensory words they mentioned during 
the class discussion. All groups added some new sensory details to their SDC to be used in their descriptive writing in the second post-test.

\subsubsection{Reflecting}

There were no significant challenges students faced during the process of learning. The common problem emerged was only about some students who prefer working individually in their daily learning. However, in this learning, students were reinforced to cooperate and collaborate with their friends. Students who were motivated in learning, like it or not, finally would actively participate in learning activities. Then, as a conclusion, there are three points to consider for future implementation. They are to reinforce students' motivation, to build more confidence in doing the discussion, and to build stronger grammar knowledge and skill.

\subsection{Post-test 2}

Post-test 2 was held after conducting Cycle 2. The topic given to the students in the test was about Lasiana Beach. It ran for 45 minutes. Each student has their own SDC and vocabulary of senses as references in writing their descriptive text. The following figure shows the results of students' descriptive writing in post-test 2 . The figure obviously performs better quality of students' descriptive writing. All students could produce longer text than the previous texts in pre- and post-tests. They also could organize the text much better.

The results of post-test 2 show that the quality of students' descriptive writing has increased significantly by $56.53 \%$. The number of students whose score is lower than the mean score has decreased by $21.42 \%$. Moreover, there is $88.88 \%$ decrease in the number of students whose quality of writing in the poor level. The highest level is achieved by $31.81 \%$ number of students.

TABLE 3: Increase in Mean Scores of Writing Quality in Post-test 2.

\begin{tabular}{|c|c|c|c|c|c|c|}
\hline & Ideas & Organization & Voice & Word choice & $\begin{array}{c}\text { Sentence } \\
\text { fluency }\end{array}$ & Conventions \\
\hline Post-test 2 & 89.77 & 75.56 & 72.15 & 75.56 & 71.02 & 54.54 \\
\hline Increase & 32.56 & 28.45 & 19.75 & 27.01 & 30.18 & 18.01 \\
\hline$\%$ & 56.91 & 60.39 & 37.69 & 55.63 & 73.89 & 49.30 \\
\hline
\end{tabular}




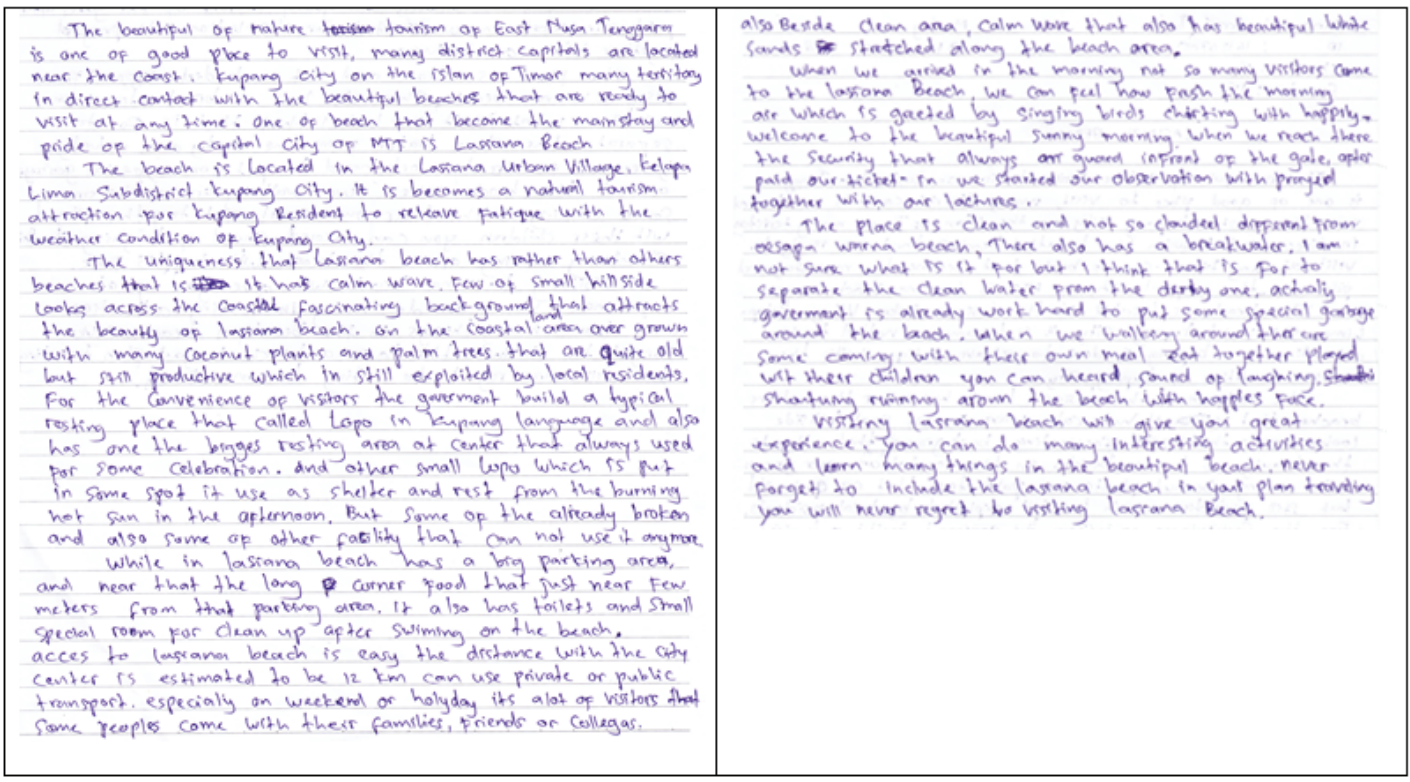

Figure 4: The Longest Descriptive Writing in Post-Test 1.

Compared to pre-test results, each aspect of writing quality in post-test 2 has increased respectively in ideas for $63.58 \%$, in the organization for $60.39 \%$, in the voice for $37.69 \%$, in word choice for $55.63 \%$, in sentence fluency for $73.89 \%$, and in conventions for $49.30 \%$. All increases have proven that the use of SDC in CEL has significantly improved the quality of students' descriptive writing in terms of ideas, organization, voice, word choice, sentence fluency, and conventions.

\section{Conclusions and Suggestions}

Based on the findings of the pre-test and post-test results, the researcher concludes that the use of sensory detail chart in collaborative experiential learning can significantly increase students' quality of descriptive writing in the six traits of writing, namely ideas, organization, voice, word choice, sentence fluency, and conventions. The researcher believes that the increases are mostly influenced by the more detail descriptions students could gain from the collaborative work and direct experience in observing the object being described. The use of sensory detail chart is also beneficial in organizing students' ideas so that they can record all detail information from the observation.

The researcher then suggests the use of sensory detail chart in collaborative experiential learning be applied to EFL students, especially in writing English descriptive text. Further researches related can use this study as a reference. The use of sensory detail chart in collaborative experiential learning then implies for the students to gain 
more ideas and detail information to improve the quality of other text structures, such as narration, exposition, and persuasion. The implementation of strategies used in this research is applicable for all level of EFL learners by adjusting the use of target sensory words in the text.

Further, the strategies used in this research are beneficial to develop the four Cs (Communication, Collaboration, Critical Thinking, and Creativity) in EFL learning. Communication takes place among the students when they work in collaboration. Teachers can reinforce their students to communicate by sharing ideas. Collaboration emerges when students try to find the best ideas and meaningful information to complete one another's. Therefore, students are forced to think critically to sort and share their ideas and information so that everyone in their group is able to get the same message. Creativity is involved in learning during the process of expressing what they observe into uncommon but exact and proper words. Since students gain benefits from the implementation of collaborative experiential learning facilitated with sensory detail chart, the researcher argues that the implementation of the strategies can increase students' quality of descriptive writing and the development of the four Cs in EFL learning.

\section{References}

[1] Akbari, Z. (2015). Current challenges in teaching/learning English for EFL learners: The case of junior high school and high school. Procedia Social and Behavioural Sciences, 199, pp.394-401.

[2] Alfaki, I. M. (2015). University students' English writing problems: diagnosis and remedy. International Journal of English Language Teaching. 3(3), pp.40-52.

[3] Dooley, M. (2008). Constructing knowledge together. Telecollaborative Language Learning. A guidebook to moderating intercultural collaboration online. Dooly, M. (ed.), pp. 21-45. Bern: Peter Lang Retrieved from http://pagines.uab.cat/melindadooly/ sites/pagines.uab.cat.melindadooly/files/Chpt1.pdf

[4] Gee, D. (2012). Learning to write with all five senses. North Hawaii News. Thursday, June, 14, p. 9.

[5] Knapp, P. \& Watkins, M. (2005). Genre, text, grammar: Technologies for teaching and assessing writing. Australia: UNSW Press Book.

[6] Kolb, A. Y. \& Kolb, D. A. (2017). Experiential learning theory as a guide for experiential educators in higher education. ELTHE: A Journal for Engaged Educators, 1(1), pp. 7-14.

[7] Laal, M. \& Ghodsi, S. M. (2012). Benefits of collaborative learning. Procedia Social and Behavioural Sciences, 199, pp. 486-490. 
[8] Langan, J. (2010). Exploring Writing: Sentences and Paragraphs. New York: McGrawHill Companies, Inc.

[9] Marpaung, T. (2017). Using collaborative sensory detail chart to increase number of content words of students' descriptive writing. ELT in Asia in the Digital Era: Global Citizenship and Identity. Proceedings of the $15^{\text {th }}$ Asia TEFL and $64^{\text {th }}$ TEFLIN International Conference on English Language Teaching, Yogyakarta, Indonesia, July 13-15, 2017. Unedited volume. Yogyakarta: UNY Press.

[10] Sharlanova, V. (2004). Experiential Learning. Trakia Journal of Sciences. 2(4), pp. 36 39. Bulgaria: Trakia University.

[11] Westwood, P. (2008). What Teachers Need to Know about Reading and Writing Difficulties. Australia: ACER Press. 